\title{
Does shelterwood regeneration on natural Scots pine sites under changing environmental conditions represent a viable alternative to traditional clear-cut management?
}

\author{
Jakub Brichta*, Lukáš Bílek, Rostislav Linda, Jan Vítámvás \\ Czech University of Life Sciences Prague, Faculty of Forestry and Wood Sciences, Kamýcká 129, CZ - 16500 Prague - Suchdol, \\ Czech Republic
}

\begin{abstract}
In the context of climate change, the crucial question is how silvicultural treatments should be modified, in order to reach favourable conditions for initiating natural regeneration of forest stands. The aim of the study was to evaluate the influence of clear-cutting, basal area reduction $(0.4,0.6$ and 0.8$)$ and soil preparation (milling cutter, forestry mulcher, brush rake and control variant without soil preparation) on the regeneration of Scots pine (Pinus sylvestris L.) in the conditions of natural pine sites (Northern Bohemia). Seedling numbers, heights and crown widths were recorded on transects representing all combinations of stand densities treatments and soil preparations variants three years after the silvicultural operations. Seed traps were installed to determine the numbers of seeds from 2016 to 2018. Soil water potential (Delmhorst Instrument Company) and soil temperature (sensor Pt1000 A-class sensors, EMS Brno) were measured. All variants of soil preparation had higher numbers of seedlings compared to control variant. When comparing stand densities, total numbers of seedlings were the highest in stand density 0.4 (cutter 32,402 \pm 34,208 S.D. ind.ha ${ }^{-1}$; mulcher 26,832 $\pm 24,088$ S.D. ind.ha ${ }^{-1}$; rake 24,496 $\pm 22,913$ S.D. ind.ha ${ }^{-1}$ ). This stand density was also beneficial with respect to seed numbers, seedling characteristics and soil moisture and temperature characteristics. We conclude that shelterwood regeneration on natural Scots pine sites is promising silvicultural approach and may become an important tool in mitigating negative effects of climate change in the future.
\end{abstract}

Key words: stand density, soil preparation, fructification, natural regeneration, soil moisture, soil temperature

Editor: Dušan Kacálek

\section{Introduction}

Scots pine (Pinus sylvestris L.) is the main tree species in half of Europe's forests (Sharma et al. 2017; Lundqvist et al. 2019). Its natural occurrence is associated with dry and/or poor sites with limited competition of climax tree species (Linder 1997; Musil \& Hamerník 2007; Vacek et al. 2010, 2019). Although pine is mainly considered resistant to limited water availability, pine stands all across Europe have been massively damaged by repeated drought events in recent years (Merlin et al. 2015; Vacek et al. 2016, 2017; Gao et al. 2017; Buras et al. 2018). Drought is probably the primary factor of damage that triggers the infestation with bark beetles and fungal diseases (Hódar \& Zamora 2004; Dobbertin et al. 2007; Wermelinger et al. 2008) or mistletoe (Viscum album L.) (Rigling et al. 2010; Zweifel et al. 2012; Mutlu et al. 2016). Mature stands with homogenous structure and often of unsuitable ecotype are mostly affected (Bottero
\& Vacchiano 2015, van Halder et al. 2019).

Basic tool for increasing the adaptability of forest stands to changing environmental conditions is their spatial structuring (Schütz 2002; del Río Gaztelurrutia et al. 2017; Ameztegui et al. 2017) and species mixing (Czerepko 2004; Pretzsch et al. 2013; Zeller et al. 2017; Vacek et al. 2019b). It is expected that such stands have greater resistance to biotic and abiotic disturbances, thus these silvicultural approaches can also become an effective tool to mitigate climate change due to the increased carbon storage (Ercanli 2018).

However, on natural pine sites the option of species mixing is very limited and the main approach remains spatial structuring (Montero et al. 2001; Gaudio et al. 2011a; Kojola et al. 2012; Spathelf \& Ammer 2015). Besides different thinning regimes in young stands that mostly create structural heterogeneity within one cohort of trees, in mature stands shelterwood regeneration creates temporal stand structures that rest on two partially 
overlapping tree generations. In addition to the common clear-cuts with or without retained seed-trees, different forms of shelterwood management in different parts of Scots pine natural range are in the scope of silvicultural research (Montero et al. 2001; Gaudio et al. 2011a; Kojola et al. 2012; Spathelf \& Ammer 2015; Bílek et al. 2016; Tullus et al. 2018; Lundqvist et al. 2019). These alternative methods include uniform large-scale shelterwood as well as small-scale management approaches that result into multi-layered Scots pine stands.

Shelterwood regeneration is a common management practice in Scandinavian countries (Hyppönen et al. 2013; Lundqvist et al. 2019), Germany (Spathelf et al. 2015; Drössler et al. 2017), Poland (Bielak et al. 2014; Aleksandrowicz-Trzcińska et al. 2017), and also in some parts of the Czech Republic (Bílek et al. 2017; 2018). It is often stated that shelterwood regeneration is more favourable with respect to microsite characteristics (Montero et al. 2001; Matías \& Jump 2012; Aleksandrowicz-Trzcińska et al. 2017; Vítámvás et al. 2019) and compared to clear-cut area, lower light intensity can lead to higher quality of pine regeneration (Pardos 2017; Schönfelder et al. 2017, 2018; Lundqvist et al. 2019). In the context of climate change, the crucial question is how temperature and moisture characteristics of the microsite can be improved with silvicultural approaches and which treatment is leading to the success of natural regeneration.

Although sporadic studies referring to ecological plasticity of pine suggest very strong competitiveness of pine regeneration (Picon-Cochard et al. 2006), it is distinctly more sensitive to root competition compared to shade tolerant species (Erefur et al. 2008) and pine seedlings usually do not succeed in dense herbal cover of blueberry (Vaccinium myrtillus L.) or heather (Calluna vulgaris [L.] Hull.) (Hyppönen et al. 2013). Thus, on natural pine sites it is not only necessary to decrease the stand density, but also to disturb the soil surface in order to promote natural regeneration (Varmola et al. 2004; Saursaunet \& Matrisen 2018).

In natural conditions the competition of ground vegetation if often temporarily supressed by fires (Eengelmark et al. 1994; Corace 2009). In the absence of these natural processes that would stimulate pulses of natural regeneration, in managed stands soil preparation using different techniques is necessary (Ackzell 1993; Barbeito et al. 2011; Aleksandrowicz-Trzcińska et al. 2014; Saursaunet \& Matrisen 2018). They should lead to higher density of natural regeneration and higher vitality of individual seedlings (Karlsson \& Örlander 2000). However, also some risks must be considered. High soil temperature without shading of herb cover (Bedford \& Sutton 2000; Oleskog \& Sahlen 2000), loss of nutrients from exposed soil (Piirainen et al. 2007) or freezing of root systems of regeneration individuals (Chantal et al. 2003) are among the most important. Ploughing and soil milling are the most common techniques of forest soil preparation. However, as these techniques are expensive, it is also common to use disc harrow or brush rakes instead (Posmetyev et al. 2016).

The aim of the study was to evaluate the influence of clear-cutting, basal area reduction and soil preparation on the regeneration of Scots pine in the conditions of natural pine sites threeyears after the silvicultural operations. To assess the feasibility of shelterwood regeneration in given conditions we hypothesized that:

1) Number of seeds after seed fall increases with stand density and is the lowest in clear-cut.

2) Seedling numbers are influenced by parent stand density and soil preparation positively.

3) Seedling parameters (height and crown width) are influenced by parent stand density negatively, while the effect of soil preparation is positive.

4) Higher soil moisture and lower temperature are associated with higher stand density, the least favourable treatment with respect to moisture and temperature is the clear-cut.

\section{Material and methods}

\subsection{Study site and experimental design}

The area of interest is located near to the municipality Doksy. It is characterized by a large area of natural Scots pine sites. Forest stands in study are managed by Military Forests and Farms of the Czech Republic, state enterprise. The entire study locality (N 50³3.77548', E $14^{\circ} 43.49143^{\prime}$ ) is in a flat terrain, at $300 \mathrm{~m}$ a.s.l. Parent rock is sandstone, with dominant soil type Arenic Podzol (Soil map 2020). Mean annual air temperature is $7.3^{\circ} \mathrm{C}$ and average maximum temperature is $31.5^{\circ} \mathrm{C}$. Mean annual precipitation is $635 \mathrm{~mm}$ (Tolasz 2007).

The experimental plots were established for monitoring of natural regeneration success of Scots pine in different stand densities and soil preparation techniques. For this purpose, the parent stand was divided into 4 sections of different harvest intensities (treatments) with resulting four stand densities: clear-cut, 0.4, 0.6 and 0.8 (Table 1). Harvests were conducted in February 2016. Methodology of parent stand inventory is given in Abdollahnejad et al. (2019).

Each of the 4 treatments had a rectangle design of approx. $60 \times 250 \mathrm{~m}$. In each of these treatments of stand density, four variants $(31.25 \mathrm{~m} \times 60 \mathrm{~m})$ of soil preparation techniques were performed in two repetitions. Variants of soil preparations were following: 1) Milling cutter KSH 700 with treatment in stripes of approx. $1 \mathrm{~m}$ distance (Milling cutter); 2) Forestry mulcher Meri Crusher 1.8 ST with full-area character of preparation (Forestry mulcher); 3) Brush rake SH 01 (Brush rake); 4) Control variant without soil preparation (Control) (Fig. 1). 
Table 1. Summary stand characteristics for individual treatments of basal area reduction derived from field inventory.

\begin{tabular}{lcccc}
\hline Stand density after harvest & Stand density before harvest & $\begin{array}{c}\text { Mean G } \pm \text { S.D. } \\
{\left[\mathrm{m}^{2} \mathrm{ha}^{-1}\right]}\end{array}$ & $\begin{array}{c}\text { Mean V } \pm \text { S.D. } \\
{\left[\mathrm{m}^{3} \mathrm{ha}^{-1}\right]}\end{array}$ & $\begin{array}{c}\text { Mean N } \pm \text { S.D. } \\
{[\text { ind.ha }}\end{array}$ \\
\hline Clear-cut & 0.8 & $0.0 \pm 0.0$ & $0.0 \pm 0.0$ & 0.0 \\
0.4 & 0.8 & $10.8 \pm 4.0$ & $123.5 \pm 58.5$ & $121 \pm 34$ \\
0.6 & 0.8 & $17.8 \pm 4.2$ & $195.2 \pm 34.1$ & $234 \pm 59$ \\
0.8 & 0.9 & $24.4 \pm 3.3$ & $258.3 \pm 47.3$ & $323 \pm 45$ \\
\hline
\end{tabular}

Note: Stand density - calculated as share of measured stand volume per hectare (before and after the harvest) and the theoretical full stand volume per hectare derived from yield tables; $\mathrm{G}$ - basal area $\left(\mathrm{m}^{2} \mathrm{ha}^{-1}\right)$ after harvest; $\mathrm{G}$ - basal areal standard deviation $\left(\mathrm{m}^{2} \mathrm{ha}^{-1}\right) ; \mathrm{V}$ - wood volume $\left(\mathrm{m}^{3} \mathrm{ha}^{-1}\right)$ after harvest; $\mathrm{V}$ - wood volume after harvest standard deviation $\left(\mathrm{m}^{2}\right.$ ha $\left.{ }^{-1}\right) ; \mathrm{N}\left(\right.$ ind.ha $\left.\mathrm{a}^{-1}\right)$ - number of trees per 1 ha after harvest; Harvest intensity (\%) - calculated as percentage of harvest on the measured stand volume before harvest; S.D. - standard deviation. Wood volumes were calculated according to Petráš \& Pajtík (1991).

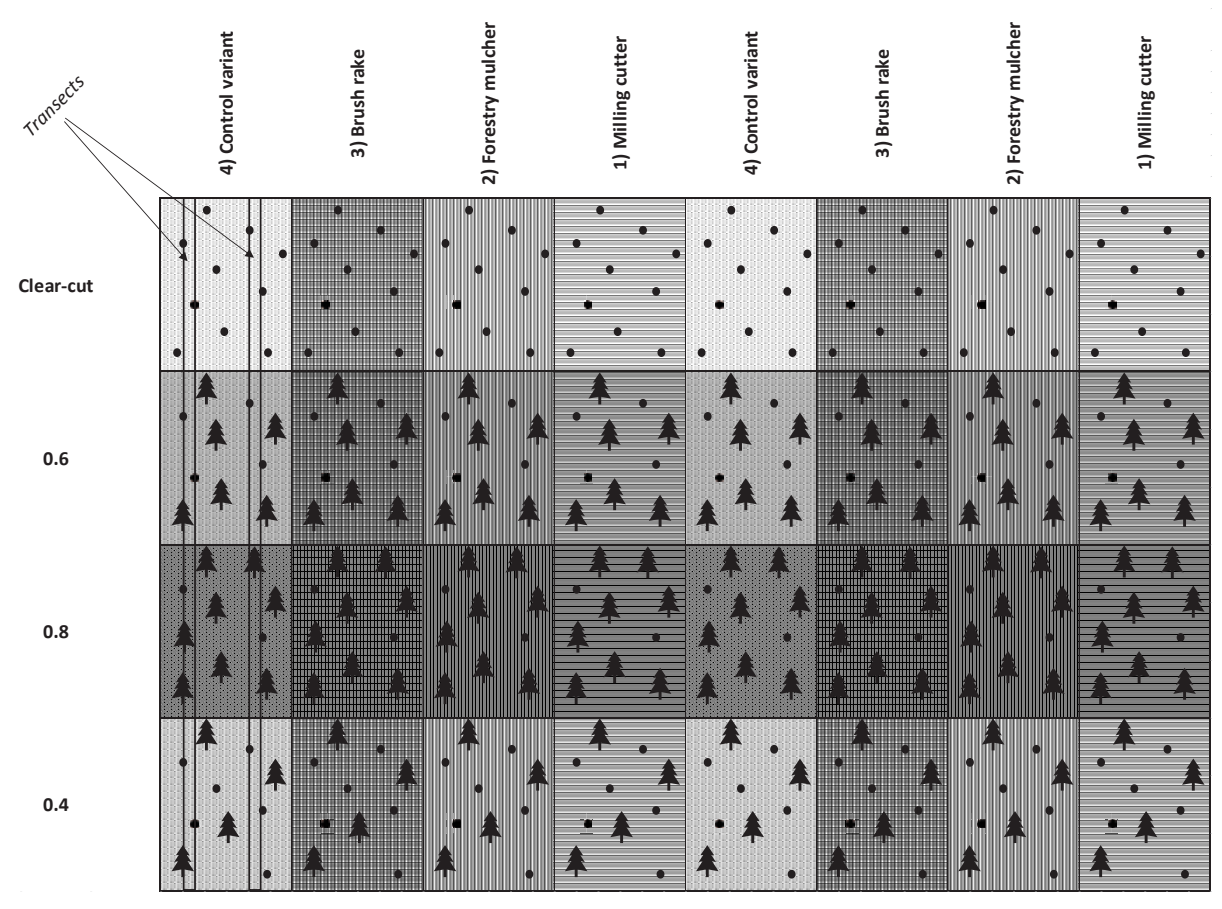

Fig. 1. Design of the experimental plot: different treatments of stand density (clear-cut; $0.4 ; 0.6 ; 0.8$ ) and different variants of soil preparation: 1) Milling cutter; 2) Forestry mulcher; 3) Brush rake; 4) Control).

\subsection{Data collection}

For each treatments of stand density and variant of soil preparation technique, two transects covering $2 \times 60 \mathrm{~m}^{2}$ each were established $(n=64)$ (Fig. 1). The transect was divided into squares of $2 \times 2 \mathrm{~m}^{2}$, for each square plot all seedlings according to species were registered. For seedlings higher than $10 \mathrm{~cm}$, total height and crown width were recorded (accuracy $1 \mathrm{~cm}$ ). All measurements were done in autumn 2018 three years after the harvest operation and soil preparation treatment.

After the harvest in 2016 in each treatment of stand density 7 seed traps (size $\left.1 \times 1 \mathrm{~m}^{2}\right)$ were placed $(\mathrm{n}=28)$. Traps were installed permanently from 2016 to 2018, each trap was placed at a boundary of two variants of soil preparations always in the middle section of each stand density treatment. Seeds were counted always in November after the end of the vegetation period.

Water potential measurement was carried out using absorption GB-2 gypsum sensor blocks (Delmhorst Instrument Company) connected to data loggers MicroLog SP3 (EMS Brno). Temperature sensor (Pt1000 A-class sensors, EMS Brno) was connected to the data- logger. The gypsum sensor blocks were placed $7-9 \mathrm{~cm}$ under the soil surface; for one stand density always 4 sensors were installed in the central part of the treatment to avoid the effect of stand edges $(n=16)$. The soil temperature (depth $7-9 \mathrm{~cm}$ ) was measured together with the soil water potential in the same position. Interval of measurements was 1 hour.

\subsection{Data analysis}

The differences in seed numbers between selected stand densities in 2016 - 2018, as well as the differences in regeneration density, seedling height and crown width between selected soil preparation techniques and stand densities were analysed by Kruskal-Wallis test, as normality of data (tested by Shapiro-Wilk normality test) was violated in all cases. Subsequent multiple comparisons were conducted according to Siegel and Castellan (1988). The soil water potential and soil temperature were plotted separately for each stand density treatments, in case of soil temperature, one-week moving average curves are also shown. 
All computations were performed using R ( $\mathrm{R}$ Core Team 2019), plots were made by "ggplot2" (Wickham, 2016) and "ggpubr" (Kassambara, 2020) packages. All statistical tests were conducted at significance level $\alpha=$ 0.05 .

\section{Results}

\subsection{Seed numbers}

The highest mean seed numbers per $1 \mathrm{~m}^{2}$ were registered for stand density 0.8 (58 \pm 16 S.D. in 2016, respectively $37 \pm 11$ S.D. in 2017, respectively $41 \pm 7$ S.D. in 2018). Conversely, during the whole observation period the lowest mean seed numbers per $1 \mathrm{~m}^{2}$ were consistently registered on clear-cut area (stand density 0.0) (4 43 S.D. in 2016 , respectively $4 \pm 1$ S.D. in 2017 , respectively: $2 \pm$ 2 S.D. in 2018). Stand densities 0.4 and 0.6 were intermediate in seed numbers, nevertheless statistically significant differences were registered mostly for stand density 0.0 (Fig. 2).

\subsection{Regeneration density}

Regeneration density for different stand densities and soil preparation techniques 3 years after the harvest is displayed in Fig. 3C. Generally, all variants of soil preparation had higher numbers of seedlings compared to control variant. Total numbers of seedlings were the highest in stand density 0.4 . The highest mean total number of seedlings was registered for following combinations of stand density treatment and soil preparation variant: 0.4
- cutter $\left(32,402 \pm 34,208\right.$ S.D. ind. ha $\left.{ }^{-1}\right) ; 0.4-$ mulcher $\left(26,832 \pm 24,088\right.$ S.D. ind.ha $\left.{ }^{-1}\right)$ and $0.4-$ rake $(24,496 \pm$ 22,913 S.D. ind.ha $\left.{ }^{-1}\right)$. Conversely, the lowest mean total number of seedlings was registered for the variant $0.5-$ control (5,972 $\pm 12,897$ S.D. ind.ha $\left.{ }^{-1}\right)$ and 0.7 - control $\left(5,960 \pm 9,047\right.$ S.D. ind.ha $\left.{ }^{-1}\right)$.

Number of seedlings lower than $10 \mathrm{~cm}$ (Fig. 3A) had the highest density in combinations 0.4 - cutter $\left(19,824 \pm 29,340\right.$ S.D. ind.ha $\left.^{-1}\right)$ followed by 0.8 - cutter $\left(15,090 \pm 18,847\right.$ S.D. ind.ha $\left.{ }^{-1}\right)$ and $0.4-$ rake $(13,876 \pm$ 17,230 S.D. ind.ha-1). The worst with respect to seedlings numbers were the control variants in combination with stand density treatment $0.6(4,037 \pm 10,097$ S.D.) and $0.8\left(3,990 \pm 7,240\right.$ S.D. ind.ha $\left.{ }^{-1}\right)$.

Number of seedlings higher than $10 \mathrm{~cm}$ (Fig. 3B) was the highest in combination clear-cut - cutter $(14,979$ \pm 16,654 S.D. ind.ha $\left.{ }^{-1}\right)$ and 0.4 - cutter $(12,578 \pm$ 14,894 S.D.ind.ha $\left.{ }^{-1}\right)$. The controlvariant showed thelowestvaluesinall cases of stand density treatments $(0.0: 4,980$ \pm 4,656 S.D. ind.ha ${ }^{-1}$; 0.3: 3,780 \pm 5,036 S.D. ind.ha ${ }^{-1}$; 0.6: 1,898 $\pm 3,758$ S.D. ind.ha ${ }^{-1}$; 0.8: 1,970 \pm 3,682 S.D. ind.ha ${ }^{-1}$ ).

\subsection{Seedlings characteristics}

Superior mean heights of seedlings were observed in stand density treatments clear-cut (stand density 0.0 ) $(20.0-21.9 \mathrm{~cm})$ and $0.4(18.0-21.3 \mathrm{~cm})$. In all soil preparation variants, there were significantly lower seedlings in stand densities $0.6(13.7-18.3 \mathrm{~cm})$ and $0.8(13.5$ $-15.7 \mathrm{~cm}$ ) (Fig. 4). The stand density treatment 0.0 was also superior with respect to crown widths of individual seedlings (19.6 - 21.3 cm) (Fig. 5).

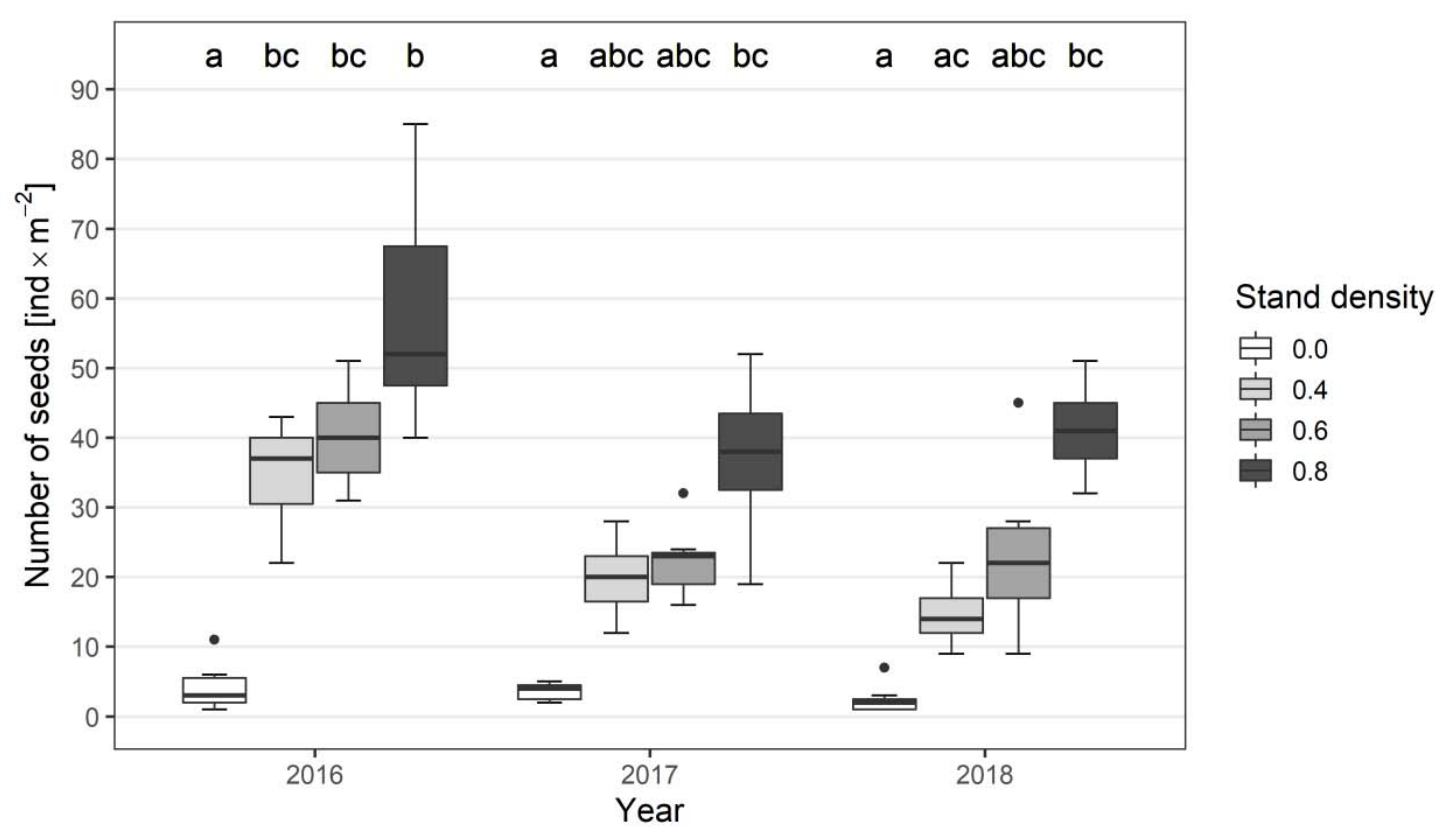

Fig. 2. Number of seeds per $1 \mathrm{~m}^{2}$ in different stand densities. Different letters indicate significant differences among groups $(p<0.05)$; values represent medians of number of seeds, upper and lower quartile. 


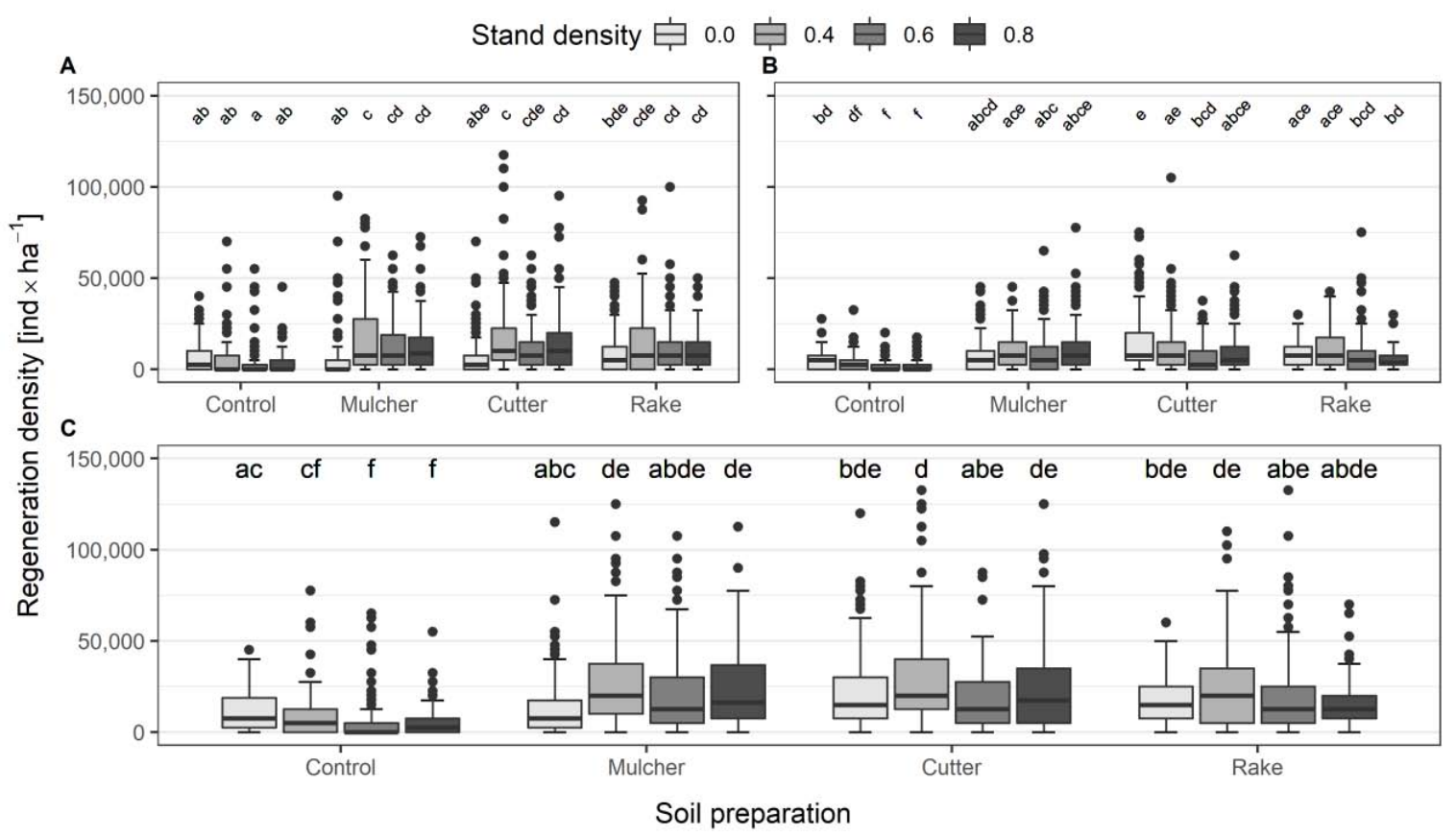

Fig. 3. Numbers of seedlings per 1 ha for different stand densities and soil preparation techniques: Number of seedlings lower than $10 \mathrm{~cm}(\mathrm{~A})$; Number of seedlings higher than $10 \mathrm{~cm}$ (B); and total number of seedlings (C). Different letters indicate significant differences between groups $(\mathrm{p}<0.05)$; values represent median, upper and lower quartile.

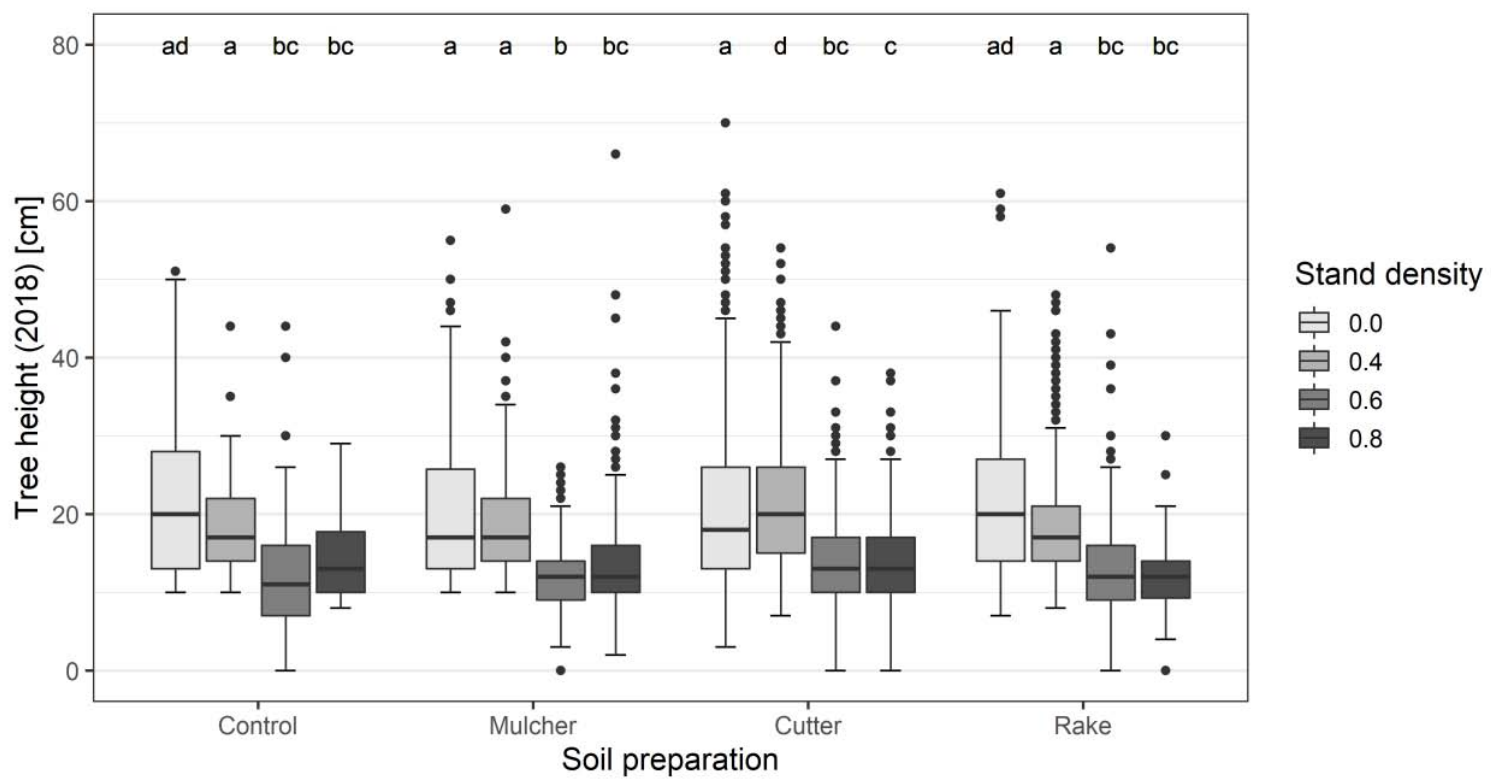

Fig. 4. Height of seedlings in different variants of soil preparation and stand density (individuals higher than $10 \mathrm{~cm}$; year 2018). Different letters indicate significant differences between groups $(\mathrm{p}<0.05)$; values represent median, upper and lower quartile. 


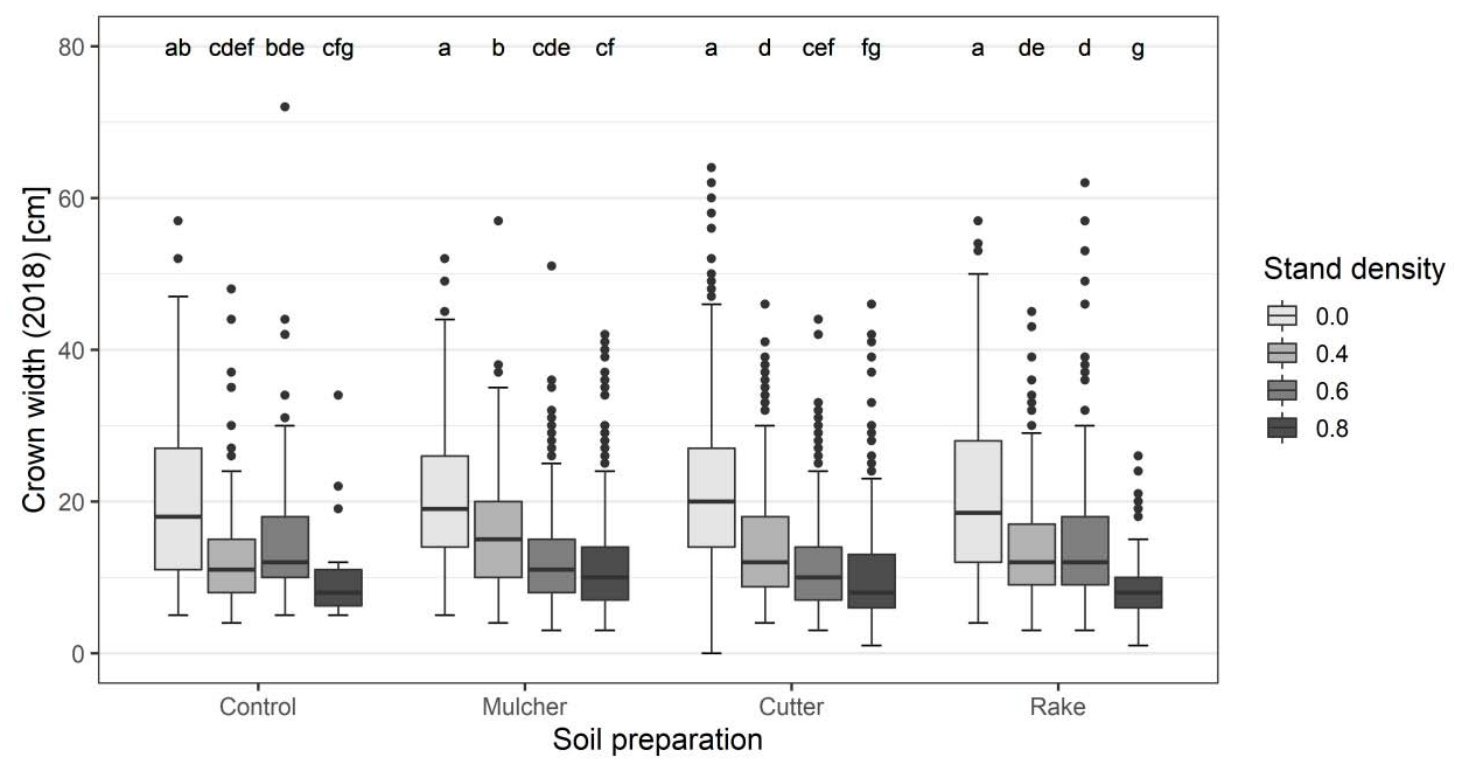

Fig. 5. Crown width of seedlings in different variants of soil preparation and stand density (individuals higher than $10 \mathrm{~cm}$; year 2018); different letters indicate significant differences between groups $(\mathrm{p}<0.05)$; values represent median, upper and lower quartile.

\subsection{Soil water potential and soil temperature}

Early increase of soil water potential was observed in stand densities 0.8 and 0.6 , whereas on clear-cut (density 0.0 ) and in stand density 0.4 the soil water potential increased with a delay and the drought period was less pronounced (Fig. 6). For example, the period with values of soil water potential above 5 bar lasted in stand density 0.8 from late June to the end of October, whereas in stand density 0.4 it lasted from early August to September.

Figure 7 shows temperatures $7-9 \mathrm{~cm}$ under the soil surface from June 2018 to November 2019. The high-

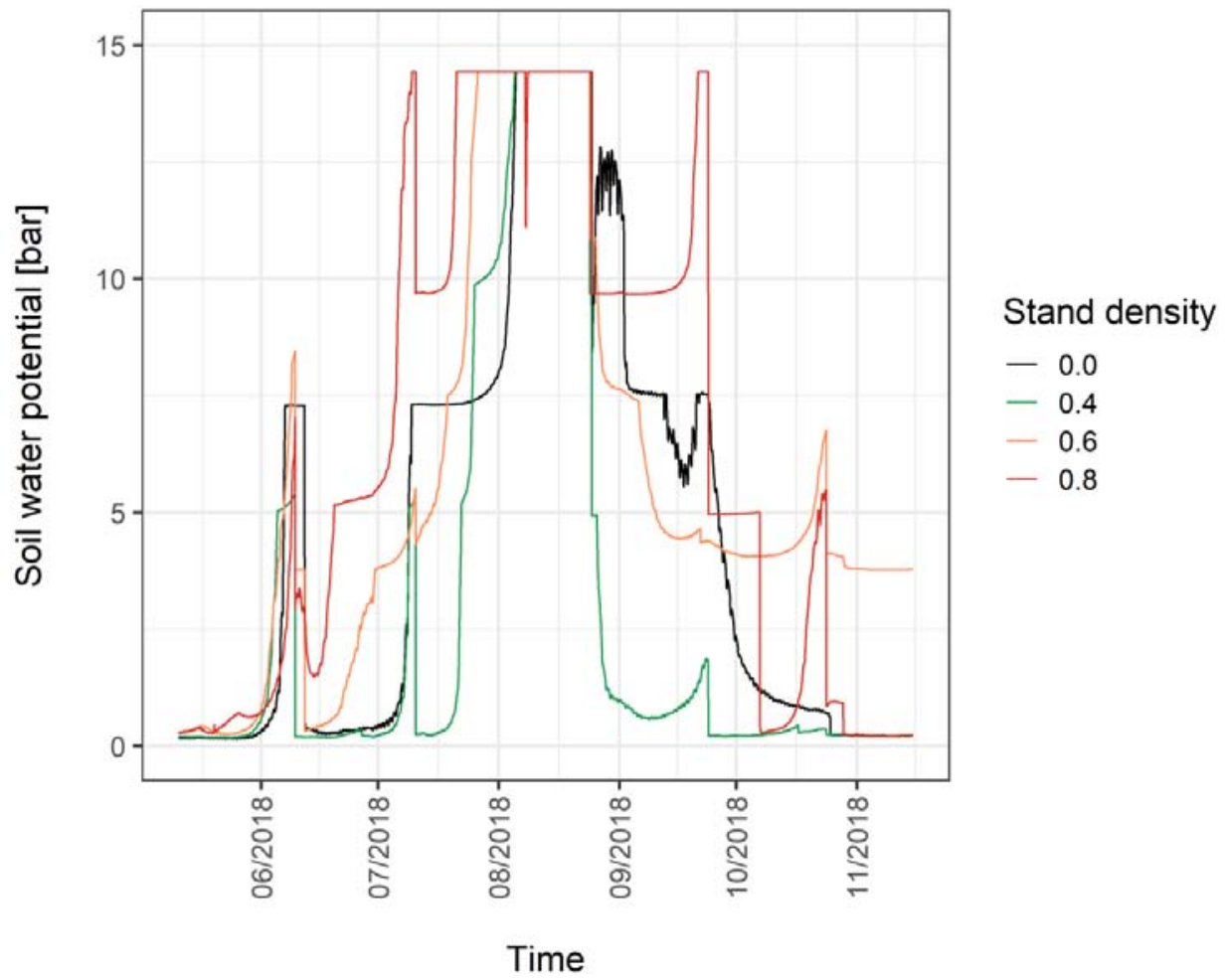

Fig. 6. Soil water potential in vegetation period 2018 for different stand densities. 


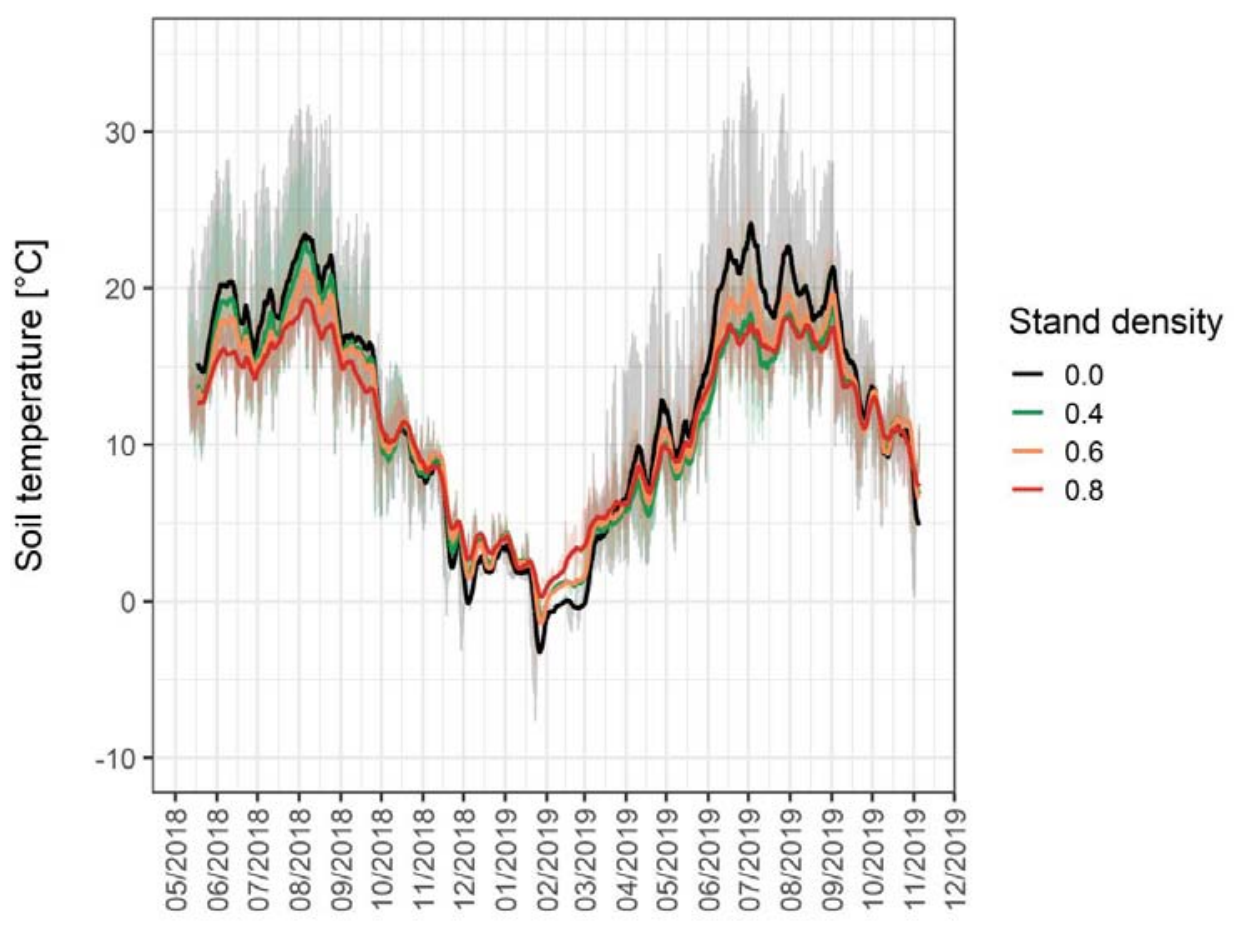

Time

Fig. 7. Soil temperature in individual months in 2018/2019 for different stand density plots. The original values (in background) are for better readability represented by one-week moving average curves.

est temperatures in summer as well as the lowest temperatures in winter were measured on clear-cut (stand density 0.0). To the contrary, the lowest amplitude of soil temperatures was observed in the case of highest stand density 0.8 . These values of stand densities 0.4 and 0.6 were between the two mentioned treatments. Generally, the absolute differences in mean temperatures between clear-cut and stand density 0.8 were the highest in July and August, intermediate in February, March and low in the remaining months.

\section{Discussion}

\subsection{Seed numbers}

In accordance with our first hypotheses, the highest seed numbers were in all years $(2016$ - 2018) recorded in the highest stand density, whereas on the clear-cut area the seed fall was the lowest. Differences between the particular stand densities from 0.4 to 0.8 were apparent, yet not statistically significant. Since most seeds are generally in close proximity to seed trees (Kuuluvainen \& Pukkala 1989), the high density of these mature individuals guarantees high seed density over the entire area. It is important to note that seed traps were placed always in the middle section of each stand density, and particularly in the case of clear-cut, higher seed numbers can be expected with decreasing distance to adjacent mature stands.
As released trees increase the diameter increment (Zdors \& Donis 2017; Brichta et al. 2019) and crown volume (Spathelf \& Ammer 2015), they probably also increase masting ability (Mukassabi etl al. 2012). As these processes are gradual and depend on the responsiveness of individual trees, with increasing time since seed harvest smaller differences in seed numbers between lower and higher stand densities can be expected. Similar results were reported by Parker et al. (2013), who stated that total seed production expressed on a per hectare and unit pine basal area basis did not differ by harvest treatment. The same authors conclude that the seed cut of the uniform shelterwood system applied to the second growth of white pine stands is unlikely to adversely affect white pine (Pinus strobus L.) seed production, seed quality, or potential for natural regeneration during mast seeding events.

\subsection{Regeneration density}

We partly reject the second hypotheses, as the most favourable conditions for seedling establishment and resulting seedling numbers 3 three years after the seed cut were reached in stand density 0.4. Parent stand density itself cannot be simply regarded as a factor with only positive effect on regeneration density. Mature trees represent competition for resources among themselves but they also have adverse effect on regeneration individu- 
als in the understory (Wiedemann 1925; Valkonen et al. 2002; Sánchez-Salguero et al. 2015). This negative effect may not be apparent immediately after the seed fall, but will increase with the growth of juvenile trees (Belend et al. 2000). Similar conclusions have been found for example by Pitt et al. (2011) in white pine stands. To the contrary, lower regeneration density on the clear-cut results probably from lower initial seed numbers as described in the first part.

Beland et al. (2000) used a similar experiment design with soil preparation by disc cutter and division of the stand into several treatments of stand density (200 stems ha ${ }^{-1} ; 160$ stems ha $^{-1}$; clear-cut area of approx. $2.5 \mathrm{ha})$. While in our study the highest seedling numbers $\left(32,402 \mathrm{ha}^{-1}\right)$ were recorded in the stand density 0.4 (approx. 121 stems $1 \mathrm{ha}^{-1}$ ), in their study for low stand density $\left(160\right.$ stems ha $\left.^{-1}\right)$ 53,000 seedlings ha ${ }^{-1}$ were reported. Even higher numbers of regeneration were then found in the stand with the highest density $\left(200\right.$ stems ha $^{-1} ; 90,000$ seedlings ha $\left.{ }^{-1}\right)$. Their study also found a very low number of seedlings on clear-cut area (3,700 seedlings ha $\left.{ }^{-1}\right)$ with cutter soil preparation, specifically this value for total number of seedlings is significantly lower than our clear-cut area values on all soil preparation variants (cutter: 21,960; mulcher: 13,550; brush rake: 17,110; control: 11,500 seedlings ha ${ }^{-1}$ ). However, our results may be affected by higher temperatures and distinct moisture deficit in 2018 (ČHMÚ 2019) resulting probably in higher seedling mortality during the vegetation period. Although pine is mainly considered resistant to limited water availability, in recent years pine stands all across Europe have been massively damaged by repeated drought events (Merlin et al. 2015; Vacek et al. 2016, 2017; Gao et al. 2017; Buras et al. 2018). Therefore, we assume that even in the local natural pine habitats, the seedlings were damaged by drought. Relatively lower stand densities are reported also from Turkey (Kara \& Topaçoğlu 2018), where 5 years after reducing the parent stand density to $50 \%$, average seedling numbers amounted to $7,000 \mathrm{ha}^{-1}$. Aleksandrowicz-Trzcińska et al. (2014) reported 9,190 seedlings ha ${ }^{-1}$ on plots after the scarification by forest plough on clear-cut of $2.5 \mathrm{ha}$.

In accordance with the second hypotheses, a positive effect of soil preparation on the seedlings numbers in all treatments of stand densities was confirmed. Similar findings were reported by many authors (Örlander et al. 1990; Karlsson \& Örlander 2000; Hille \& Ouden 2004; Barbeito et al. 2011). Besides immediate regeneration success, mainly deeper soil preparation also significantly lowers the $\mathrm{C} / \mathrm{N}$ ratio, increases the amount of $\mathrm{P}, \mathrm{Mg}$ and S (Örlander et al.1996) and supresses the competition of ground vegetation (Hille \& Ouden 2004; Nilsson et al. 2006; Gaudio et al. 2011b; Hyppönen et al. 2013). Deeper soil preparation is also recommended by Posmetyev et al. (2016), who adds that not only does it achieve good results in terms of natural regeneration density, but is also economically effective. Despite this, there are large differences in preferences and value of soil preparation according to a particular habitat (Ackzell 1993; Ammer et al. 2011; Aleksandrowicz-Trzcińska et al. 2014; Saursaunet \& Matrisen 2018).

\subsection{Seedling characteristics}

Based on our results, we confirm the hypotheses that seedling height and crown width are influenced by parent stand density negatively, nevertheless the effect of soil preparation on these regeneration parameters was not apparent.

Superior mean heights of seedlings in clear-cut and stand density 0.4 are mainly related to higher resources availability, as was confirmed also in numerous controlled experiments. Vítámvás et al. (2019) reported for 1-year-old seedlings that root length, shoot dry mass and root dry mass were the highest in full light conditions, however the differences in shoot length were not so pronounced. Riikonen et al. (2016) documented high ability of pine seedlings to respond to release cut by primarily increasing the crown width. In older literature, there are many proofs about the superior growth of young plants growing in larger distances to seed trees (eg. Wiedemann 1925).

We were not able to confirm positive effect of soil preparation on seedling growth, nevertheless Nilsson et al. (2006) and Gaudio et al. (2011b) showed superior height growth of regeneration individuals after soil scarification. The reason is better soil chemical and mechanical properties and lower competition of herbaceous vegetation (Karlsson \& Örlander 2000; Varmola et al. 2004; Saursaunet \& Matrisen 2018). To the contrary, Pierik \& De Wit (2014) related high competition of herbaceous vegetation to superior height growth, but at the expense of crown width and chlorophyll content in assimilation organs.

\subsection{Soil water potential and soil temperature}

Based on our results, we reject the hypotheses that more favourable soil moisture and temperature characteristics are associated with higher stand density, and that the least favourable treatment with respect to moisture and temperature is the clear-cut. Although the lowest amplitude of soil temperatures was observed in the case of highest stand density 0.8 , and the highest temperatures in summer as well as the lowest temperatures in winter were observed on the clear-cut, higher stand densities (0.6 and 0.8$)$ were related to lower soil moisture and possibly higher risk of drought stress for seedlings. Similar results presented several authors (Limousin et al. 2008; del Campo et al. 2014, Gebhardt et al. 2014) who stated that the release cut had a positive effect on the amount of water in the transplantation streams of mature trees, but also the soil water potential itself. The reason for the 
increase in the amount of water in the stand is mainly the lower rate of mature trees crown interception (Limousin et al. 2008), but also their lesser competition and evapotranspiration (Kellomäki et al. 1997; Giuggiolia et al. 2013). Del Campo et al. (2014) also stated that a strong stand density reduction increased the amount of water in the soil by up to $20-40 \%$.

\section{Conclusion}

Based on our research, we conclude that the best outcome of natural regeneration was achieved after seed cut decreasing the stand density to 0.4 . This was manifested by sufficient seed numbers, highest regeneration density, superior seedling characteristics and positive effect on soil moisture and temperature characteristics. The effect of soil preparation of any type was crucial for the regeneration success, but the best results were documented for treatment with milling cutter (3-fold increase in total mean numbers of seedlings compared to control variant versus 2.6-fold increase for forestry mulcher and 2.4fold increase for brush rake). We conclude that shelterwood regeneration with initial stand density reduction to 0.4 on natural Scots pine sites represents justified alternative to clear-cutting and may in the future become an important tool in mitigating negative effects of climate change.

\section{Acknowledgment}

This work was financially supported by the Ministry of Agriculture of the Czech Republic [Project No. QJ1520037] and by the Czech University of Life Sciences Prague, Faculty of Forestry and Wood Sciences (IGA no. B_19_05).

\section{Literature}

Abdollahnejad, A., Dimitrios, P., Bílek, L., 2019: An Integrated GIS and Remote Sensing Approach for Monitoring Harvested Areas from Very High-Resolution, Low-Cost Satellite Images. Remote Sensing, 11: 2539.

Ackzell, L., 1993: A comparison of planting, sowing and natural regeneration for Pinus sylvestris (L.) in boreal Sweden. Forest Ecology and Management, 61:229-245.

Aleksandrowicz-Trzcińska, M., Drozdowski, S., Wolczyk, Z., Bielak, K., Żybura, H., 2017: Effects of Reforestation and Site Preparation Methods on Early Growth and Survival of Scots Pine (Pinus sylvestris L.) in South-Eastern Poland. Forests, 8:1-17.

Kassambara, A., 2020: ggpubr: 'ggplot2' Based Publication Ready Plots. R package version 0.2.5. Available online: https://CRAN.R-project.org/ package $=$ ggpubr.
Ameztegui, A., Cabon, A., De Cáceres, M., \& Coll, L., 2017: Managing stand density to enhance the adaptability of Scots pine stands to climate change: a modelling approach. Ecological Modelling, 356:141-150.

Ammer, C., Balandier, P., Scott Bentsen, N., Coll, L., Löf, M., 2011: Forest vegetation management under debate: an introduction. European Journal of Forest Research, 130:1-5.

Ammon,W.,2009:Výběrnýprincipvlesnímhospodářství: závěry ze 40-ti let švýcarské praxe. Překlad 4. vydání. Kostelec nad Černými lesy, Lesnická práce.

Barbeito, I., LeMay, V., Calama, R., \& Canellas, I., 2011: Regeneration of Mediterranean Pinus sylvestris under two alternative shelterwood systems within a multiscale framework. Canadian journal of forest research, 41:341-351.

Bedford, L., Sutton, R. F., 2000: Site preparation for establishing lodgepole pine in the sub-boreal spruce zone of interior British Columbia: the Bednesti trial, 10-year results. Forest Ecology and Management, 126:227-238.

Beland, M., Agestam, E., Ekö, P. M., Gemmel, P., Nilsson, U., 2000: Scarification and seedfall affects natural regeneration of Scots pine under two shelterwood densities and a clear-cut in southern Sweden. Scandinavian Journal of Forest Research, 15:247-255.

Bielak, K., Dudzińska, M., Pretzsch, H., 2014: Mixed stands of Scots pine (Pinus sylvestris L.) and Norway spruce (Picea abies [L.] Karst) can be more productive than monocultures. Evidence from over 100 years of observation of long-term experiments. Forest Systems, 23:573-589.

Bílek, L., Vacek, S., Vacek, Z., Remeš, J., Král, J., Bulušek, D., Gallo, J., 2016: How close to nature is close-to-nature pine silviculture? Journal of Forest Science, 62:24-34.

Bílek, L., Remeš, J., Švec, O., Vacek, Z., Štícha, V., Vacek, S., Javůrek, P., 2017: Ekologicky orientované pěstování porostů v podmínkách nižších až středních poloh. Strnady, VÚLHM. Lesnický průvodce 9/2017.

Bílek, L., Vacek, Z., Vacek, S., Bulušek, D., Linda, R., Král, J., 2018: Are clearcut borders an effective tool for Scots pine (Pinus sylvestris L.) natural regeneration? Forest systems, 27:e010.

Bottero, D., Vacchiano, G., 2015: Repeated spring precipitation shortage alters individual growth patterns in Scots pine forests in the Western Alps. Trees, 29:1699-1712.

Brichta, J., Bílek, L., Vacek, Z., 2019: Stem diameter increment of mature Scots pine trees after release cut. In: Proceedings of Central European Silviculture. Brno 3. - 5. 9. 2019. MENDELUv Brně, p. 192-201.

Buras, A., Schunk, C., Zeiträg, C., Herrmann, C., Kaiser, L., Lemme, H., Menzel, A., 2018: Are Scots pine forest edges particularly prone to drought-induced mortality? Environmental Research Letters, 13:025001. 
Chantal, M. D., Leinonen, K., Ilvesniemi, H., Westman, C. J., 2003: Combined effects of site preparation, soil properties, and sowing date on the establishment of Pinus sylvestris and Picea abies from seeds. Canadian Journal of Forest Research, 33:931-945.

Corace, R.G., III, Goebel, P.C., Hix, D. M., Casselman, T. Seefelt, N. E., 2009: Ecological forestry at National Wildlife Refuges: experiences from Seney National Wildlife Refuge and Kirtland's Warbler Wildlife Management Area, USA. The Forestry Chronicle, 85:695-701.

Czerepko, J., 2004: Development of vegetation in managed Scots pine (Pinus sylvestris L.) stands in an oak-lime-hornbeam forest habitat. Forest ecology and management, 202:119-130.

del Campo, A. D., Fernandes, T. J. G., Molina, A. J., 2014: Hydrology-oriented (adaptive) silviculture in a semiarid pine plantation: How much can be modified the water cycle through forest management? European Journal of Forest Research, 133:879-894.

del Río Gaztelurrutia, M., Oviedo, J. A. B., Pretzsch, H., Löf, M., Ruiz-Peinado, R., 2017: A review of thinning effects on Scots pine stands: From growth and yield to new challenges under global change. Forest systems, 26:9.

Dobbertin, M., Wermelinger, B., Bigler, C., Bürgi, M., Carron, M., Forster, B., Rigling, A., 2007: Linking increasing drought stress to Scots pine mortality and bark beetle infestations. The Scientific World Journal, 7:231-239.

Drössler, L., et al., 2017: Natural Regeneration in a Multi-Layered Pinus sylvestris-Picea abies Forest after Target Diameter Harvest and Soil Scarification. Forests, 8:35.

Engelmark, O., Kullman, L., Bergeron, Y., 1994: Fire and age structure of Scots pine and Norway spruce in northern Sweden during the past 700 years. New Phytologist, 126:63-168.

Ercanli, İ., 2018: Positive effect of forest structural diversity on aboveground stand carbon stocks for even-aged Scots pine (Pinus sylvestris L.) stands in the Sarıçiçek Forest, Northern Turkey. Scandinavian Journal of Forest Research, 33:455-463.

Erefur, CH., Bergsten, U., Chantal, M., 2008: Establishment of direct seeded seedlings of Norway spruce and Scots pine: effects of stand conditions, orientation and distance with respect to shelter tree, and fertilisation. Forest Ecology and Management, 255:1186-1195.

Gao, Y., Markkanen, T., Aurela, M., Mammarella, I., Thum, T., Tsuruta, A. et al., 2017: Response of water use efficiency to summerdrought in a boreal Scots pine forest in Finland. Biogeosciences, 14:4409-4422.

Gaudio, N., Balandier, P., Perret, S., Ginisty, C., 2011a: Growth of understorey Scots pine (Pinus sylvestris L.) saplings in response to light in mixed temperate forest. Forestry, 84:187-195.
Gaudio, N., Balandier, P., Philippe, G., Dumas, Y., Jean, F., Ginisty, C., 2011b: Light-mediated influence of three understorey species (Calluna vulgaris, Pteridium aquilinum, Molinia caerulea) on the growth of Pinus sylvestris seedlings. European Journal of Forest Research, 130:77-89.

Gebhardt, T., Häberle, K.H., Matyssek, R., Schulz, C., Ammer, C., 2014: The more, the better? Water relations of Norway spruce stands after progressive thinning. Agriculture and Forest Meteorology, 197:235-243.

Giuggiola, A., Bugmann, H., Zingg, A., Dobbertin, M., Rigling, A., 2013: Reduction of stand density increases drought resistance in xeric Scots pine forests. Forest Ecology and Management, 310:827-835.

Hille, M., Den Ouden, J., 2004: Improved recruitment and early growth of Scots pine (Pinus sylvestris L.) seedlings after fire and soil scarification. European Journal of Forest Research, 123:213-218.

Hódar, J. A., Zamora, R., 2004: Herbivory and climatic warming: a Mediterranean outbreaking caterpillar attacks a relict, boreal pine species. Biodiversity \& Conservation, 13:493-500.

Hyppönen, M., Hallikainen, V., Niemelä, J., Rautio, P., 2013: The contradictory role of understory vegetation on the success of Scots pine regeneration. Silva Fennica, 47:19.

Kara, F., Topaçoğlu, O., 2018: Influence of stand density and canopy structure on the germination and growth of Scots pine (Pinus sylvestris L.) seedlings. Environmental monitoring and assessment, 190:749.

Karlsson, C., Öerlander, G., 2000: Soil scarification shortly before a rich seed fall improves seedling establishment in seed tree stands of Pinus sylvestris. Scandinavian Journal of Forest Research 15:256-266.

Kellomäki, S., Väisänen, H., Kolström, T., 1997: Model computations on the effects of elevating temperature and atmospheric $\mathrm{CO}_{2}$ on the regeneration of Scots pine at the timber line in Finland. Climatic Change, 37:683-708.

Kojola, S., Ahtikovski, A., Hökkä, H., Penttilä, T., 2012: Profitability of alternative management regimes in Scots pine stands on drained peatlands. European Journal of Forest Research, 131:413-426.

Kuuluvainen, T., Pukkala, T., 1989: Effect of Scots pine seed trees on the density of ground vegetation and tree seedlings. Silva Fennica, 23:159-167.

Linder, P., Elfing B., Zackrisson, O., 1997: Stand structure and successional trends in virgin boreal forest reserves in Sweden. Forest Ecology and Management, 98:17-33.

Lundqvist, L., Aahlström, M. A., Axelsson, E. P., Mörling, T., Valinger, E., 2019: Multi-layered Scots pine forests in boreal Sweden result from mass regeneration and size stratification. Forest Ecology and Management, 441:176-181. 
Matías, L., Jump, A. S., 2012: Interactions between growth, demography and biotic interactions in determining species range limits in a warming world: The case of Pinus sylvestris. Forest Ecology and Management, 282:10-22.

Merlin, M., Perot, T., Perret, S., Korboulewsky, N., Vallet, P., 2015: Effects of stand composition and tree size on resistance and resilience to drought in sessile oak and Scots pine. Forest Ecology and Management, 339:22-33.

Montero, G., Cañellas, I., Ortega, C., del Rio, M., 2001: Results from a thinning experiment in a Scots pine (Pinus sylvestris L.) natural regeneration stand in the Sistema Ibérico Mountain Range (Spain). Forest Ecology and Management, 145:151-161.

Mukassabi, T. A., Polwart, A., Coleshaw, T., Thomas, P. A., 2012: Scots pine seed dynamics on a waterlogged site. Trees, 26:1305-1315.

Musil, I., Hamerník, J., 2007: Jehličnaté dřeviny: přehled nahosemenných i výtrusných dřevin: lesnická dendrologie 1. Academia, 352 p.

Mutlu, S., Osma, E., Ilhan, V., Turkoglu, H. I., Atici, O., 2016: Mistletoe (Viscum album) reduces the growth of the Scots pine by accumulating essential nutrient elements in its structure as a trap. Trees, 30:815-824.

Nilsson, U., Örlander, G., Karlsson, M., 2006: Establishing mixed forests in Sweden by combining planting and natural regeneration-effects of shelterwoods and scarification. Forest ecology and management, 237:301-311.

Oleskog, G., Sahlén, K., 2000: Effects of seedbed substrate on moisture conditions and germination of Scots pine (Pinus sylvestris) seeds in a mixed conifer stand. New Forests, 20:119-133.

Örlander, G., Egnell, G., Albrektson, A., 1996: Longterm effects of site preparation on growth in Scots pine. Forest Ecology and Management, 86:27-37.

Örlander, G., Gemmel, P., Hunt, J., 1990: Site preparation: a Swedish overview. FRDA report 105. Ministry of Forests, Research Branch, Victoria.

Pardos, M., Montes, F., Aranda, I., Cañellas, I., 2007: Influence of environmental conditions on germinant survival and diversity of Scots pine (Pinus sylvestris L.) in central Spain. European Journal of Forest Research, 126:37-47.

Pardos, M., Pérez, S., Calama, R., Alonso, R., Lexer, M. J., 2017: Ecosystem service provision, management systems and climate change in Valsaín forest, central Spain. Regional environmental change, 17:17-32.

Parker, W. C., Noland, T. L., Morneault, A. E., 2013: Comparative mast seed production in unmanaged and shelterwood white pine (Pinus strobus L.) stands in central Ontario. New forests, 44:613-628.

Petráš, R., Pajtík, J., 1991: Sústava česko-slovenských objemových tabuliek drevín. Lesnícky časopis, 37:49-56.
Picon-Cochard, C., Coll, L. Balandier, P., 2006: The role of below-ground competition during early stages of secondary succession: the case of 3-year-old Scots pine (Pinus sylvestris L.) seedlings in an abandoned grassland. Oecologia, 148:373-383.

Pitt, D., Morneault, A., Parker, W., Lanteigne, L., Hoepting, M., Stinson, A., 2011: Influence of herbaceous and woody competition on white pine regeneration in a uniform shelterwood. The Forestry Chronicle, 87:653-668.

Pierik, R., De Wit, M., 2014: Shade avoidance: phytochrome signalling and other aboveground neighbour detection cues. Journal of Experimental Botany, 65:2815-2824.

Piirainen, S., Finér, L., Mannerkovski, H., Starr, M., 2007: Carbon, nitrogen and phosphorus leaching after site preparation at a boreal forest clear-cut area. Forest Ecology and Management, 243:10-18.

Posmetyev, V. I., Zelikov, V. A., Drapalyuk, M. V., Latysheva, M. A., Shatalov, E. V., 2016: Substantiation and evaluation of effectiveness of perspective constructions of forest tractors ancillary equipment. Journal of Engineering Applied. Sciences, 11:1840-1855.

PortálČHMÚ, (2019): Historická data-Územní teploty [online]. Praha. Available online: http://portal.chmi. cz/historicka-data/pocasi/uzemni-srazky.

Pretzsch, H., Bielak, K., Block, J., Bruchwald, A., Dieler, J., Ehrhart, H. P. et al., 2013: Productivity of pure versus mixed stands of oak (Quercus petraea [Matt.] Liebl. and Quercus robur L.) and European beech (Fagus sylvatica L.) along an ecological gradient. European Journal of Forest Research, 132:263-280.

R Core Team, 2019: R: A language and environment for statistical computing. R Foundation for Statistical Computing, Vienna, Austria. Available online: https://www.R-project.org/.

Riikonen, J., Kettunen, N., Gritsevich, M., Hakala, T., Särkkä, L., Tahvonen, R., 2016: Growth and development of Norway spruce and Scots pine seedlings under different light spectra. Environmental and experimental botany, 121:112-120.

Saursaunet, M., Mathisen, K., Skapre, C., 2018: Effects of Increased Soil Scarification Intensity on Natural Regeneration of Scots Pine Pinus sylvestris L. and Birch Betula spp. L. Forests, 9:262.

Sánchez-Salguero, R., Linares, J. C., Camarero, J. J., Madrigal-González, J., Hevia, A., Sánchez-Miranda, Á., Rigling, A., 2015: Disentangling the effects of competition and climate on individual tree growth: a retrospective and dynamic approach in Scots pine. Forest Ecology and Management, 358:12-25.

Sharma, R.P., Bílek, L., Vacek, Z., Vacek, S., 2017: Modelling crown width-diameter relationship for Scots pine in the central Europe. Trees, 31:1875-1889. 
Schönfelder, O., Zeidler, A., Borůvka, V., Bílek, L., 2017: Influence of site conditions and silvicultural practice on the wood density of Scots pine (Pinus sylvestris L.) - a case study from the Doksy locality, Czech Republic. Journal of Forest Science, 63:457-462.

Schönfelder, O., Zeidler, A., Borůvka, V., Bílek, L., Lexa, M., 2018: Shrinkage of Scots pine wood as an effect of different tree growth rates, a comparison of regeneration methods. Journal of Forest Science, 64:271-278.

Siegel, S., Castellan, Jr. N. J., 1988: Nonparametric statistics for the behavioral sciences, 2nd ed. McgrawHill Book Company, New York, NY, England.

Spathelf, P., Ammer, C., 2015: Forest management of scots pine (Pinus sylvestris L) in northern Germany - a brief review of the history and current trends. Forstarchiv, 86:59-66.

Spathelf, P., Bolte, A., van der Maaten, E., 2015: Is closeto-nature silviculture (CNS) an adequate concept to adapt forests to climate change? Landbauforschung, 65:161-170.

Soil Map. Available online: http://www.geology.cz/ extranet-eng/services/web-applications/ (accessed on11 March 2020).

Tolasz, R., 2007: Atlas podnebí Česka (Climate atlas of Czechia), 1st ed., Praha, Český hydrometeorologický ústav, Univerzita Palackého v Olomouci, 255 p.

Tullus, T., Rosenvald, R., Leis, M., Lõhmus, P., 2018: Impacts of shelterwood logging on forest bryoflora: Distinct assemblages with richness comparable to mature forests. Forest Ecology and Management, 411:67-74.

Vacek, S., Nosková, I., Bílek, L., Vacek, Z., Schwarz, O., 2010: Regeneration of forest stands on permanent research plots in the Krkonoše Mts. Journal of Forest Science, 56:541-554.

Vacek, S., Vacek, Z., Bílek, L., Simon, J., Remeš, J., Hůnová, I. et al., 2016: Structure, regeneration and growth of Scots pine (Pinus sylvestris L.) stands with respect to changing climate and environmental pollution. Silva Fennica, 50:1564.

Vacek, S., Vacek, Z., Remeš, J., Bílek, L., Hůnová, I., Bulušek, D. et al., 2017: Sensitivity of unmanaged relict pine forest in the Czech Republic to climate change and air pollution. Trees, 31:1599-1617.
Vacek, S., Vacek, Z., Bílek, L., Remeš, J., Hůnová, I., Bulušek, D. et al., 2019a: Stand dynamics in natural Scots pine forests as a model for adaptation management? Dendrobiology, 82:24-42.

Vacek, Z., Vacek, S., Slanař, J., Bílek, L., Bulušek, D., Štefančík, I. et al., 2019b: Adaption of Norway spruce and European beech forests under climate change: from resistance to close-to-nature silviculture. Central European Forestry Journal, 65:129-144.

Valkonen, S., Ruuska, J., Siipilehto, J., 2002: Effect of retained trees on the development of young Scots pine stands in Southern Finland. Forest Ecology and Management, 166:227-243.

van Halder, I., Castagneyrol, B., Ordóñez, C., Bravo, F., del Río, M., Perrot, L., Jactel, H., 2019: Tree diversity reduces pine infestation by mistletoe. Forest Ecology and Management, 449:117470.

Varmola, M., Hyppönen, M., Mäkitalo, K., Mikkola, K., Timonen, M., 2004: Forest management and regeneration success in protection forests near the timberline in Finnish Lapland. Scandinavian Journal of Forest Research, 19:424-441.

Vítámvás, J., Bílek, L., Ulbrichová, I., Bažant, V., Dreslerová, J., Vacek, Z., 2019:Vzcházení, přežívánía kořenový systém semenáčků borovice lesní (Pinus sylvestris L.) při různých intenzitách slunečního záření a závlahy. Zprávy lesnického výzkumu, 64:102-110.

Wermelinger, B., Rigling, A., Schneider Mathis, D., Dobbertin, M., 2008: Assessing the role of bark-and wood-boring insects in the decline of Scots pine (Pinus sylvestris) in the Swiss Rhone valley. Ecological Entomology, 33:239-249.

Wickham, H., 2016: ggplot2: Elegant Graphics for Data Analysis.

Wiedemann, E., 1925: Die praktischen Erfolge des Kieferndauerwaldes. Verlag von Friedr. Vieweg \& Sohn, Braunschweig, 184 p.

Zdors, L., Donis, J., 2017: Evaluating the edge effect on the initial survival and growth of scots pine and Norway spruce after planting in different size gaps in shelterwood. Baltic Forestry, 23:534-543.

Zeller, L., Ammer, C., Annighöfera, P., Biber, P., Marshall, J., Schütze, G., Pretzsch, H., 2017: Tree ring wood density of Scots pine and European beech lower in mixed-species stands compared with monocultures. Forest Ecology and Management, 400:363374. 